\title{
Critical Reflection and Communities of Practice as Professional Development Strategies for Educators
}

\author{
Devi Akella, Anna Gibbs, Belinda Gilbert, Brandon Henry \\ Valerie Lee, Daphine Mathis, Victor Williams \\ Albany State University, GA, USA
}

\begin{abstract}
The research focus of this paper contributes to the areas of critical reflection, communities of practice, professional development, and best teaching practices. Critical reflection is a mechanism whereby educators can self-assess themselves, their teaching practices, and pedagogies to develop into better educators in the future. This paper provides empirical evidence from an educators' community of practice to demonstrate how reflection, dialogue and collaboration can be embedded within a teaching profession. Self-reflexive autoethnographic accounts of six professors working in a higher education institution are considered to understand how the process of reflection and dialogue as a collaborative exercise can make educators more aware of their strengths and weaknesses and provide avenues for self-improvement to develop professionally.
\end{abstract}

\section{Introduction}

Reflection, or rather reexamination and reevaluation, can turn out to be powerful transformation tools for the teaching profession. Usually dismissed as a waste of time or as too time consuming, reflection leads to a continuous process of learning and selfimprovement which can help an educator personally and professionally Boud [1], Dewey [2]. Reflection is a process, whereby educators can learn about themselves, their students, the course content, the classroom environment and redevelop themselves as educators Williams and Power [3]. Educators are aware that their student populations keep changing and they need to constantly adapt to their students, keeping in mind their social and economic backgrounds Marentic Pozarnik [4]. Reflection provides the educators this chance to revisit the past, critically review their methods, fix, or repair their teaching pedagogies and emerge as better educators in the future. By assessing one's inner strengths and weaknesses, considering both what went right and what went wrong in the past i.e., pinpointing what should be repeated and avoided in the future, with a focus on answering questions such as "why", "what", "how come", with regards to instructional techniques, it returns power back to the individuals so that they can effectively control their future actions thereby changing everyday classroom life Korthagen and Vasalos [5], Liu [6], Schon [7]. Critical reflection enables a bottom-up approach towards professional development, by starting with the qualities and values ingrained within the educators to allow development of "quality from within" Korthagen and Vasalos [5]. Critical reflection thus provides an alternative reconceptualized approach to learning and teaching where examining daily events can "lead to new and extra-ordinary insights" Brandenburg [8].

Reflection entails a quiet and systematic process of stepping back into the past, which can be undertaken as an individual or as a group-based exercise. If undertaken as a group activity, it possesses the capability to build connections with professionals within one's academic disciplines and outside one's academic disciplines resulting in strong friendships, partnerships, and networking groups. These personalized, collaborative reflective conversations also have the potential of generating a toolbox of best teaching practices, class activities and problem-based solutions for both online and face to face teaching modalities. Thus, this process of constant questioning and looking inward not only creates a sense of selfawareness and ability to control one's future actions and behavior, resulting in professional development, and transformation into a better educator Korthagen and Vasalos [5], Liu [6]. But also, in the generation of evidence-based research data, which can be used to further improve teaching practices.

In other words, collaboration, dialogue, and reflection can become the passwords to a teacher's success in the classroom. However, despite agreeing on the relevance of these three components (i.e., collaboration, dialogue, and reflection) in the context of educators' professional development, there is a lack of understanding regarding how this process of reflection can be embedded within the teaching profession. How can educators embark on the process of reflection and how can this process be integrated into the daily lives of 
educators in higher education institutions (HEIs)? are some questions which have been left unexplored. There is a large gap pertaining to how critical reflection can practically be put into practice Saric and Steh [9]. The question "how does the process of reflection look like in the actuality of teachers' professional lives" remains unanswered Saric and Steh [9]. The paper overcomes this gap by providing empirical evidence on how the above three components can be effectively integrated into the daily working lives of educators at a HEI. In addition, the model of communities of practice and its effectiveness in convening groups of educators, to dialogue, share and reflect about themselves as teachers and their teaching practices is also considered.

The entire paper has been divided into four sections. Section one looks at the role of reflection in the teaching profession, in specific different theoretical and philosophical models. The next section provides information about the research method and information pertaining to the research participants. Section three consists of the empirical data and analysis, which demystifies teaching methods and their overall effectiveness. The last section consists of concluding thoughts and directions for further research.

\section{Critical Reflection and Teaching Profession}

According to Freire [10], educators are "unfinished" resources who are in a continuous state of evolvement. Educators are always engaged in a process of constantly learning, reflecting, unlearning and then relearning again, a never-ending process of constantly trying to understand their students and adopting suitable teaching pedagogies to reach out to them, engage them, and disseminate knowledge to them -"recreating and remaking knowledge" Freire [10]. Students' needs and wants are constantly changing, one student generation might be different from the other in terms of personality characteristics, perceptions about the world and learning styles. Reflection enables educators to confront their attitudes pertaining to human nature, human potential, and human learning Freire [10], through a brutal process of "describing, informing, confronting and reconstructing" events and experiences" Smyth [11]. They develop better practices in the future by thinking critically about their current practices and through in-depth introspection Freire [10].

Schon [7]'s seminal work which provides the initial conceptual understandings pertaining to reflective practice, argues that all professional educators possess prior tacit knowledge and skill, which they use to teach their respective classes and impart knowledge to their students. During reflection episodes, educators reflect on this prior knowledge, their classroom strategies and beliefs about teaching and learning, to make sense of what works in their classes and what does not. The critical insights gained from these postmortem reflections influence one's future actions, or if undertaken as a collaborative group, are shared, and discussed to initiate forward action planning Schon [7]. The entire reflective activity involves a temporary unsettlement, confrontation with one's mistakes and failures, resolving ethical dilemmas, learning from the past and acceptance of a changed practice Benade [12]. Even though the entire process can be described as unsettling and disturbing, it is also a process which liberates educators from their preconceived notions and myths concerning themselves and their students Williams and Power [3]. Critical reflection is therefore a crucial aspect of professional development for all educators Schon [7]. It is a proactive cognitive activity which examines current situations, practices, and techniques to move towards higher levels of quality performances in the future Brookfield [13].

Educators should be trained to continuously engage in critical reflection, to emerge as subject matter experts, autonomous, responsible, and ethical instructors Korthagen and Vasalos [5], Marentic Pozarnik [4]. Critical reflection has the power to convert the teaching profession into an action-oriented research activity [9]. Educators in their roles as "selfcritical learners and problem posting educators", can research their teaching methods, seek to understand the process of teaching, and their students, their identities, and ideologies. While teaching emerges as a transformative process, where new teaching modalities, pedagogical techniques and grading mechanisms can be designed and transferred effectively into classrooms at regular time intervals Benade [12].

\section{Communities of Practice: Sharing, Dialogue and Reflecting}

Ghaye, A. and Ghaye [14] argue that critical reflection can be more effective if it can be developed as a social exercise, so that the reflective conversations of the educators can widen the knowledge boundaries of the education community. The paper considers the effectiveness of the communities of practice model in engaging educators as a collaborative group to share their insights in a dialogic format, to critically reflect and professionally develop as educators. Communities of Practice (COP) are a group of professional people who share similar interests and convene together to improve their skills and learn from each other's experiences Lave and Wenger [15].

Six educators, four females and two males in the age groups between 25-45 years, of African American and Caucasian race, belonging to different academic 
disciplines, working at MU, a pseudo name for a historically black university (HBCU), came together for a semester to form a collaborative group, a community of practice on scholarship of teaching and learning (SOTL). The objective of SOTL community of practice (COP) was to engage in a series of dialogue on what teaching pedagogies and practices worked in their classrooms, what technological modalities were successful in engaging this new student population, millennials, and Generation $\mathrm{Z}$ and how they could further improve their teaching and the learning of their students. The participants were interested in learning about themselves, learning from each other, learning about their students, and critically reflecting on these insights to become educators who understood their students better.

MU is located in southern part of USA, and offers associate, bachelors, and master's degrees. The HEI has over 6000 students, predominantly of African American origin, with a small number of Caucasian and Asian students. Majority of MU's students are African Americans, first generation college goers belonging to lower economic strata of the society who lack prior exposure to college life, are mentally unprepared for the challenges and the academic rigor which being a college student entails. Their high school training proves to be inadequate, and without access to friends and family members who may have attended college, they are usually left floundering without sufficient expertise and knowledge on how to handle academic demands. The educators at MU are always under pressure to engage their students and maximize their student learning. New pedagogies which incorporate technology and social media, constant experimentation with interpersonal techniques to establish rapport with one's students are pressing demands.

All six participants of the SOTL COP met on fortnight basis either face to face or virtually to discuss classroom experiences, what modalities worked for them, what did not, and what technological tools were preferred by the students and so on. At the end of the semester, they decided to pen their reflective experiences using a five-dimensional paradigm: cognitive (intellectual), affective (emotional), motivational (goals and objectives), personal (social origin and personality), and bodily dimensions (professional values) to understand how individuals reflect and how this process transforms them as professionals Korthagen and Vasalos [5], Williams and Power [3].

The six participants wrote their reflections in the form of narrative autoethnographies using the fivedimensional parameter, which traced their reflection journeys: who am I (personal dimension)? What works for me in the classroom and what does not work for me in the classroom (cognitive dimension)? Why do I feel this works for me or does not (affective dimension)? How can I improve myself as an educator (bodily and motivation dimensions)? [see Figure 1]. These five dimensions show similarities to the onion model developed by Korthagen and Vasalos [5], a multi-level learning approach where an educator's mission (what inspires me?), identity (who am I?), beliefs (what do I believe?), competencies (what am I competent at?), behavior (what do I do?) and finally environment (what do I encounter?) are the connecting points for the entire reflection exercise. However, the dimensions suggested in this paper are more encompassing because they cover aspects such as need for self-improvement and motivation as well.

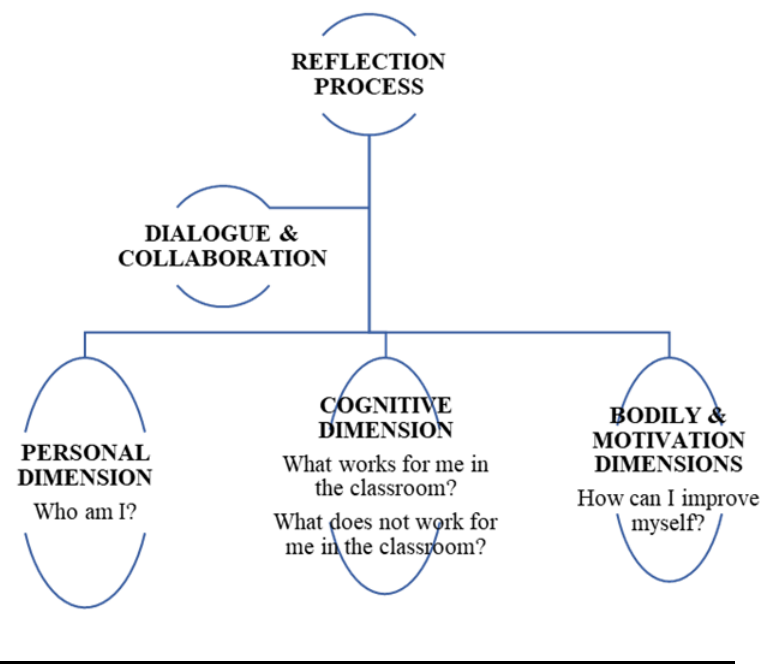

Figure 1. Dimensions of Reflection Paradigm (adapted from Korthagen and Vasalos [5])

To continue with autoethnographic accounts, these research methods are popular in academics, as tools of reflexive learning capable of examining everyday organizational phenomena Greiner [16]. Educators simultaneously take up the roles of practitioners and researchers and explore their teaching profession, pedagogies, and students. Educators are now the research subjects themselves, the academic researchers and the change agents who redefine the meaning of teaching practices. While truthful and realistic accounts recorded straight from the teaching field can be used as evidence-based accounts useful for professional development purposes.

The empirical analysis consisted of reviewing the six self-reflexive autoethnographic narratives. All six autoethnographies were read, and then reread a couple of times for the emergence of common themes to gain 
critical insights about the individual as an educator and human being, their thinking processes and teaching practices and subsequently their transformation. To further exemplify all six reflective autoethnographies were compared with each other, to notice similarities if any in terms of types and effectiveness of each instructor's teaching pedagogies, their perceptions of their students, their approaches towards their students (how they created rapport, bonds, and relationships), and their capacity to be completely honest about their mistakes and failures. The role of collaboration and dialogue in this entire process of reflection was also considered. The next section discusses the empirical data and empirical analysis.

\section{Action, Reflection and Learning: The Transformation Process}

The six autoethnographic narratives were examined to understand how a person can transform as a result of critical reflection. The empirical analysis started with the individual educators, their identities, then what worked and did not work for them, and why they interpreted their actions in a certain manner and how one changed by participating in the SOTL COP Brookfield [13]. An additional theme revolved around the role of collaboration and dialogue in this entire process of critical reflection.

\subsection{The Beginning - The Identity of the Educator}

The identity of the educator can be the first stage of the entire reflection exercise, because it is the “organizing element in teachers' professional lives... a resource that [educators] can use to explain, justify and make sense of themselves in relation to others and to the world at large" Maclure [17], Neumayer Depiper [18]. The identity of the educator, or rather grappling with a series of questions such as "who am I? and Who do I want to become?" Akkerman and Meijer [19], allows individuals to assess themselves and what they do in the classrooms and how the reflection process transforms them in the long run.

Identities can be considered the beginning points from where the educator's teaching philosophy, instructional pedagogies and classroom management strategies evolve. Identities influence the educators thinking processes and their approaches towards their students Korthagen and Vasalos [5]. For instance, Anna reveals in her narrative:

"I am a 25-year-old Caucasian female. I was born in 1994. I come from an upper-class family and experienced a wonderful childhood. I attended
University from years 2012 to 2018. During this time, I gained my bachelor's degree in Exercise science and my master's degree in Kinesiology from the University. My passions include disease prevention through exercise intervention, as well as, utilizing exercise technique to improve athletic performance. Throughout college I personally trained and led group fitness. Upon graduation, I additionally obtained a certification as a strength and conditioning specialist...I began my first career as the senior center's programs and activities manager...managing the fourteen county senior centers, I expanded my knowledge on geriatric wellness... In 2019, I left that job.... I am currently an instructor of Health and Human Performance ... ". (Anna)

Anna is a Caucasian, fresh from college, new to the community, to the university and to teaching. She is passionate about exercise, health, and fitness. Anna's passion, theoretical grounding, practical experience, and age would prove to be her plus points within a classroom. She is also a millennial, and therefore might show a preference for technology and action-oriented teaching strategies. However, being a Caucasian from a higher economic background working in a HBCU, she would confront cultural issues unless she adopts culturally relevant teaching pedagogies.

Daphine in her reflection provides in-depth insights about her background and upbringing. Unlike Anna, she is an African American, from a different economic setup where education was considered as a medium to move up in life. Her reflection stressed upon the values of hard work, compassion, and dreams. For her, becoming a nurse educator was a dream and a highlight of her career. In the words of Daphine:

"I am a 41-year-old female and the Maternal-Child Educator... Like many of us, choosing nursing as a career was brought on by past experiences. Growing up I remember as a little girl nursing on my grandfather, taking his temperature and helping to care for his recently amputated leg. I am a very caring and compassionate person and always felt the need to help. As the oldest of four siblings, I was taught responsibility early. My parents had me at a young age and they depended on me to help as the eldest child while they attended work and school to better themselves. Seeing my parents work hard at their personal goals and aspirations helped to develop me into the person I am today. From them, I learned the importance of education... while working there, I learned one significant aspect of nursing; it's not just a job or a profession; it's a way of life...". (Daphine)

To continue, identity formation is not only an attribute of one's economic, social, and racial background it is also a continuous process in 
development. Usually in the initial career stages, there is a conflict between personal and professional ideologies, which creates a confused multifaceted identity till one reconciles and accepts certain views about teaching and one's students Maclure [17]. As Valerie, another educator around the same age as Anna wrote:

"In my first year of instructing, I found a few strategies to work and a number of approaches not to work with regards to my instruction... When I treat students as friends, I have found they are more comfortable in class, during instruction. I am relatable, so students let guards down, and classroom discussions are more so conversations. Students are more open and willing to be receptive to criticisms with some of the relationships that have developed because they feel valued...". (Valerie)

In the above reflection, Valerie is still learning what works for her in the classroom, and what sort of teacher she would like to be. She realizes being in her students' age group she can be more effective by reaching out to them as a friend and building rapport with them. This creates a comfort zone for her students, to let their guards down and engage with her on a more equal footing. And as the educator gains experience, all these learning experiences interconnect and submerge into a teaching ideology. The educators gradually define teaching through experimentation with different teaching mechanisms, interactions with students and their views about the curriculum and the educational system Henry [20]. The following reflections support the above theoretical assertions.

"I began my undergraduate matriculation in August of 1999. At that time, more traditional forms of instruction were employed in my classes. Because it was college, there was no more hand holding like I received in secondary school, meaning that I could not rely on the use of study guides and other materials (like worksheets) to supplement my learning and prepare for exams. I had to learn how to study and take notes properly as well as utilize excellent time management to ensure that I remained on track with my studies...

Twenty years later and after several years of serving in the role as a faculty member, I have realized that I cannot utilize the same approach that my professors used with me and my classmates. We currently teach a generation of students who feel more entitled and expect everything to be given to them instead of them working diligently and truly seeking knowledge and earning their grades. To that end, as a professor, I consistently remind my students of upcoming deadlines in many different ways: verbal announcements in class, through emails, announcements in Georgia View (our online learning platform) and messages through RemindMe (an app that allows for communication beyond the classroom)". (Brandon)

Brandon realized that the teaching techniques used by his teachers when he was in college had now become obsolete. Because he was teaching a different generation of students, he had to change himself, his teaching philosophy and teaching modalities -teaching pedagogies had to be adapted to the learning styles of students. So unlike Anna and Valerie he had to make the effort to adapt himself to his students' needs and demands. Brandon's revelations are similar to Victor's who had been teaching for over twenty years and had realized the need to constantly evolve himself and his teaching style to suit the students and their learning styles.

"Over the last 20 years that I have been teaching students I have noticed that there are a lot of factors that students in the past did not have. Today's students have anxiety and stress that students in the fifty and sixty did not have. Different generations have their own learning styles and as a professor it is up to me to ensure that I continue to adjust my teaching style to the learning of the students...". (Victor)

Teaching as a practice is thus not only influenced by the educators, their personalities, upbringing, educational backgrounds, age, and ideologies. But the identity of the educators also keeps changing, resulting in simultaneous changes to their teaching philosophies. See below:

"I find myself to be a slightly humorous person, and... it definitely boosts the enjoyability of the material I present in class. I've realized that it turns complicated or seemingly boring content into really exciting content". (Valerie)

"However, I know that I will need to stay flexible because with new generations come new challenges to learning". (Victor)

All educators need to make a conscious effort to take up the roles of change agents, generate evidencebased research by sharing and compiling their successes and failures and integrate others best teaching practices to guide their teaching efforts. These were in fact the exact reflections of Belinda:

"Professors must be supportive of evidence-based research and utilize research to guide practice. As a professor, I must ensure adequate processes are in place to empower students ...". (Belinda) 
The next section considers the reflections of the six participants on what worked and did not work for them in the classroom, in terms of interpersonal styles, teaching pedagogies, classroom management skills and communication strategies (affective dimension) and how this triggered self-improvements and professional development (bodily and motivation dimensions).

\subsection{Teachers' Revelations and Transformations}

The six reflections considered different techniques which had proved effective and ineffective for them in their classrooms. The educators mentioned that using technology and social media, giving continuous feedback, discussing the syllabus, providing extensive out of class support, proved effective for them. For instance, Belinda split her classes into time-division slots of 10 to 15 minutes each, encompassing a mixture of information and activity sessions keeping in mind the short attention span of her students Bradbury [21]. As Belinda mentioned in her reflection:

"I must plan my day, where I am mindful of a student's short attention span, which is about 15 minutes. So, I may discuss a subject/topic for 15 minutes then move to an active-learning strategy such as a group casestudy”. (Belinda)

She was aware that the new generation of students, the Generation Z, needed instant information otherwise they tended to get restless Cilliers [22]. So, during the first day of class she reviewed the course syllabus in detail and then navigated her students through the entire course learning management system emphasizing due dates and course expectations.

"Another crucial task is to review the course syllabus with students and take them on a navigational tour through the course learning management system. The tour will allow students to locate vital information within their course shell”. (Belinda).

All six educators acknowledged the importance of technology in the classrooms. Their reflections mentioned different mechanisms via which technology was being integrated into their teaching processes. All students had Facebook accounts, contacted their lecturers through social media, preferred WhatsApp to receive and share information with their classmates Cilliers [22]. Two of the educators, Anna and Valerie happened to belong to the same generation as their students, and therefore were in alignment with the students' preferences and choices.
"As a millennial, I had a unique understanding of how my students engage in technology outside of the classroom" (Anna).

The educators therefore used virtual games, social media, textbooks in electronic format and cell phones to engage their students in the classrooms. For instance, Daphine mentioned:

"These strategies include PowerPoint, recorded lectures, real-life scenarios, low and high-fidelity simulation, ... to reinforce topic learning. I also incorporate role-play, games such as Kahoot and Jeopardy, and pass the chicken to bring the information all together". (Daphine)

Brandon was doing something similar in his classrooms as well:

"Playing games, like Kahoot, is mobile-friendly, highly engaging and more effective than more traditional question-and-answer review sessions". (Brandon)

Belinda's reflection mentioned technological pedagogies specifically suited for her nursing students, such as:

"...live simulation conducted by the professor, where they have pre-briefing and post-briefing. These simulations allow students to ask questions and perform various skills in a safe area utilizing high-tech mannequins without harming a live patient". (Belinda)

Different forms of student activities using technology were popular with students, such as Kahoot, Jeopardy, ticket out of class and simulations utilizing high-tech mannequins which recreated the hospital and patient environments for the nursing students. In fact, all participants were using a virtual based learning platform known as Kahoot where material was presented in the form of an interactive game, which assessed students' knowledge levels. Belinda, Daphine, Brandon, Valerie and Anna all mentioned that Kahoot was highly popular with their students.

“... I've incorporated the use of Kahoot!, which is a game-based learning platform that brings full class engagement. I've discovered that students are more prepared for assessments using Kahoot. Material presented in the form of an interactive game, gives students the chance to test, present knowledge of material previously covered. I use it as somewhat of a review before assessments." (Valerie)

Pedagogical methods such as power points, recorded lectures, social media channels such as Facebooks and 
making mobile phones a part of the overall teaching process were also mentioned. Victor was using social media in his classrooms to establish rapport with his students. He had Facebook pages for all his classes. As recorded in his reflection:

"I also go over how to use Facebook as well as other social media platforms for the class. I have a Face book page for each class that I teach". (Victor)

Brandon had realized he could not win against students' mobile devices and had instead integrated them to increase student engagement and achievement. He explained how:

"When I present course topics using Microsoft PowerPoint, I have the students to sign into an app called Nearpod on their mobile devices. Once signed in, the presentation that I am using in class populates on their devices, which allows me to control what they are viewing on the device. Therefore, the students must follow along with me as I am delivering the information they need. Additionally, this provides me an opportunity to assess mastery of the content as I can incorporate check-in questions that students answer on their mobile devices". (Brandon)

Belinda also mentioned the students' preference for open educational resources which allowed the students to access their textbooks on their laptop computers, iPads and even on their smartphones. She therefore tried to identify electronic textbooks for her students:

"...the use of an eBook. Students have access to their textbook via their laptop, iPad, or smartphone with the added benefit of following the professor highlighted notes or creating their own notes". (Belinda)

The participants' reflections revealed that it was not just technology, but technology used in an interactive manner. For instance, pedagogical techniques which increased students' engagement and maximized their learning Cilliers [22]. Belinda reflected:

"It is in my experience that the use of technology, adaptive-learning exams, research engagement / presentation, real-life clinical rotation, simulation, case-studies, role-play exercises, games, PPT with recorded lectures, ... work successfully”. (Belinda)

Personalized gestures such as being interested and empathetic, learning the names of the students, calling out their names and asking questions, providing one-toone tutoring, and developing study guides for the exams were also mentioned. Each of the below excerpts denote a certain quotient of personalized touch and care:
"During the first class meeting I try to learn each student name as well as their home-town and where they are living at the time of my class". (Victor)

"I learned quickly that they preferred fillable study guides which included specific questions to answer. Though I was initially against providing the latter type of study guides, I observed that the students performed better on assessments because they had a better idea of how to prepare the assessments and on what material to focus more. I also have found that providing worksheets and more opportunities for graded assignments have helped with student achievement". (Brandon)

"With the student who was struggling, he met with me for one on one tutoring every week. Additionally, I supplied the student with supplemental work and had him redo assignments until he made over a 90\%”. (Anna)

The educators learned from each other that despite the emphasis on technology, the most popular teaching strategies involved being personal, interested, and empathetic to the needs of the students, understanding their comfort zones, providing one-to-one teaching sessions, and incorporating group-based learning activities. However, they all agreed that the importance of technology, social media in engaging students in the classrooms was undeniable. By sharing their success stories, all six participants not only learned from each other but were also able to compile a list of effective teaching practices for their Generation $\mathrm{Z}$ students.

The educators also shared their negative experiences which allowed them to learn from their mistakes and from the failure of their colleagues, thereby gaining insights which would transform them into better educators. For instance, Daphine discovered:

"I provided the students with traditional lectures utilizing only a teacher-centered approach for one module. Their grades provided me the results that I expected; the traditional teacher-centered model of an active teacher and a passive student was not the best approach”. (Daphine)

Similarly, with Belinda:

"A teacher-centered approach does not consider the needs of the students and appears as if the teacher is the only expert in the room...Student's attention span fizzles after maybe 15 minutes; therefore, long lectures do not work". (Belinda) 
Anna realized her mistake of failing to consider the culture of her students. She laments in her reflection:

"MU is classified as a Historically Black College and University. As a Caucasian, relating to my students culturally was also a challenge at first. I was unaware of music, celebrities, and some historical figures that my students frequently discuss". (Anna)

It is important for educators to be aware of the race and origin of their student learners and use culturally relevant teaching examples and content Ladson-Billings [23]. Educators need to integrate and build upon their students' cultural knowledge, previous experiences, learning and performance styles to make the overall process learning more relevant and effective LadsonBillings [23]. Anna further continues:

"Cultural differences became apparent as soon as the first semester began. As a 25-year-old Caucasian, I experienced challenges relating to some of my students and other faculty". (Anna)

However, while conversing with other COP members she became aware of culturally relevant pedagogy and incorporated it into her classrooms. Again, for Valerie and Anna who happened to be in their twenties, age was proving to be a detrimental factor in the classroom. Anna commented in her reflection:

"At age 25, many of my students were close to my age. This posed a challenge to gain respect of the class...". (Anna)

Similarly, Valerie found it difficult to maintain decorum during class discussions and debates.

"I find myself at times, instructing in a bit of an "outside voice", because I'm having to talk-over chatter. It only occurs during intense debates/ discussions over subject matter, which I enjoy but not when it gets out of hand". (Valerie)

The other participants were able to advice Anna and Valerie on how to deal with this age issue, by being firm yet caring and personal with one's students. The ability of an educator to demonstrate that they cared about their students determined their level of success in the classrooms Miller and Mills [24]. The students in the higher education valued and appreciated educators who were transparent, receptive, interested and encouraging.

"Students desire to know they are valued and have a voice. Students prefer their professor's authentic presence, constructive feedback, and encouragement". (Belinda)

In other words, it is possible to learn by reflecting on one's experiences and then sharing it with a larger group. As evident from the above reflections the educators revisited their previous episodes and situations, reassessed, and reexamined themselves critically and resolved their problems collaboratively and reflexively to maximize student learning and engagement. The next section considers the role of dialogue and collaboration in this entire reflection process resulting in transformations and subsequently professional development.

\subsection{Dialogue and Collaboration}

Communities of practice effectively allow employees to interact, share and learn from each other. The participants learn through engagement and collaboration, reflection, and common understandings Wenger [25]. All the six educators reflected about themselves, and their teaching experiences leading to professional development, but this solitary process of reflection was turned into a social exercise through dialogue and collaboration. This is evident from Anna's statement:

"The COP allowed me to come out of my comfort zone and to explore ... I feel working as a group made it so much easier and enjoyable. The group was awesome, and I got to know them." (Anna)

The COP model allowed the participants to connect with new faculty members, emerge from their comfort zones, establish connections, talk, and share their classroom episodes. Daphine further elaborates:

"The group incorporated several faculty members from different areas... As a group, I feel we work very well together, having the ability to brainstorm and reach common solutions. ... working with the COP aid in building confidence in many of my own personal skills and abilities." (Daphine)

Other participants also supported the statements of Anna and Daphine. They found the COP model useful in creating a neutral organizational space while at work, to connect with their peers, establish bonds and learn from each other thereby resulting in professional development. COP model thus enables the educators to take up the roles of change agents who through introspection, collaboration, and dialogue, improve themselves and generate evidence-based best teaching practices (see Table 1). 


\section{Conclusion}

To conclude critical reflection can be a powerful transformative tool for all educators if it is practiced at regular intervals. As a collaborative exercise, it is more constructive, because not only does the educator learn from his/her self-reflection but also from the reflections of his/her peers Brookfield [13], Korthagen and Vasalos [5]. The COP model proves to be an innovative and collaborative method which allows educators to convene, converse, reflect and learn from each other in an informal manner while at work.

The qualitative study demonstrated the effectiveness of the COP model in creating an organizational workspace during working hours, which would allow educators to dialogue, reflect, and learn collaboratively from each other. An effort is made to understand the role of dialogue, collaboration, and reflection in professionally developing educators by incorporating the COP model in a HEI. The autoethnographic accounts of the six educators are considered to understand whether the educators engaged in dialogue, reflection and improved themselves. The empirical analysis revealed that the educators learned from each other's classroom experiences, both positive and negative (see Table 1) while reflecting and engaging in dialogue as a group. They were able to generate a list of effective teaching pedagogies such as the usefulness of interactive technology games, visual aids, group-based activities which matched the learning styles of the students, significance of personalized actions such as learning the names of the students, providing them with study guides, reviewing the syllabus on the first day of the class and providing one-on-one tutoring sessions to the students who were lagging behind in the class. This not only created a list of evidence based best teaching practices but also allowed the COP participants to undertake a comparative analysis and learn from their peers about different types of teaching pedagogies. They were also able to tackle problematic issues faced in their classrooms such as complaints pertaining to lecture based teaching strategies, not considering the culture of the students and difficulty in gaining respect of the students by being in the same age group as their students. The educators brainstormed as a group, they reflected solitarily and then shared these reflections with their peers, to provide constructive advice and suggestions to improve themselves as teachers. This paper thus provides valuable insights about COP and its effectiveness in creating a collaborative group of educators who can share, dialogue, and reflect on their successes and failures to improve themselves as educators.

Table 1. Summary of the Empirical Analysis

\begin{tabular}{|c|c|c|c|}
\hline & The Educators & The Cop Model & Professional Development \\
\hline Anna & $\begin{array}{l}\text { Young, Millennial, recently graduated, uses technology, } \\
\text { gives private tutorials to students, matches teaching aids } \\
\text { with learning styles, empathetic to students' needs. } \\
\text { Initially did not use culturally relevant teaching methods } \\
\text { in her classes. }\end{array}$ & \multirow{6}{*}{$\begin{array}{c}\text { Collaboration } \\
\text { "The group incorporated } \\
\text { several faculty members } \\
\text { from different areas." } \\
+ \\
\text { Reflection } \\
\text { “...allowed me to come out } \\
\text { of my comfort zone and } \\
\text { explore....” } \\
+ \\
\text { Dialogue } \\
\\
\text { "As a group, Ifeel we } \\
\text { work very well together, } \\
\text { having the ability to } \\
\text { brainstorm and reach } \\
\text { common solutions". } \\
= \\
\text { Professional } \\
\text { Development }\end{array}$} & $\begin{array}{c}\text { Now is a culturally relevant teacher } \\
\text { aware of how to handle students in } \\
\text { her own age group. }\end{array}$ \\
\hline Belinda & $\begin{array}{l}\text { Experienced, African American educator who initially } \\
\text { used teacher centered approaches. } \\
\text { Uses technology, E-books and OpenStax materials, } \\
\text { empathetic and sympathetic to students, reviews syllabus } \\
\text { with students, etc. }\end{array}$ & & $\begin{array}{c}\text { Now makes a conscious effort to } \\
\text { incorporate student centered teaching } \\
\text { modalities. }\end{array}$ \\
\hline Brandon & $\begin{array}{l}\text { Provides study guides for exams, integrates cell phones } \\
\text { and technology into classroom teaching. }\end{array}$ & & $\begin{array}{l}\text { Realizes he is not in the age group of } \\
\text { the students and therefore } \\
\text { consciously works on his teaching } \\
\text { modalities. }\end{array}$ \\
\hline Daphine & $\begin{array}{l}\text { African American, always wanted to be a nursing } \\
\text { instructor, earlier used teacher centered activities. } \\
\text { Matches class activities with learning styles of students, } \\
\text { uses technological pedagogies, group-based activities. }\end{array}$ & & $\begin{array}{l}\text { Shifted from teacher centered } \\
\text { activities. Consciously improves her } \\
\text { teaching strategies. }\end{array}$ \\
\hline Valerie & $\begin{array}{l}\text { Young, Millennial, recently graduated, uses interactive } \\
\text { technological pedagogies. Humorous and self-critical. }\end{array}$ & & $\begin{array}{l}\text { Learns how to improve her classroom } \\
\text { management skills. }\end{array}$ \\
\hline Victor & $\begin{array}{c}\text { Personal with students, uses Facebook and social media, } \\
\text { understanding with his students. }\end{array}$ & & $\begin{array}{l}\text { Has realized he is not in the age } \\
\text { group of his students and tries to } \\
\text { adapt his teaching practices to relate } \\
\text { to his students. }\end{array}$ \\
\hline
\end{tabular}


However, this research being a qualitative study, it was only able to integrate the feedback of six educators. To further strengthen the empirical results, studies in future might survey educators to relate reflection with teacher development and student performances. Furthermore, this paper highlights the importance of technology in the classrooms when teaching Generation $\mathrm{Z}$ and millennials. It also mentioned different types of technological modalities which can be used in classrooms. Studies in future can measure the level of student learning achieved by these technological pedagogies. Finally, with recent health epidemic concerns (i.e., COVID-19) and all education moving to online instruction, the scope for research pertaining to critical reflection and effective teaching has increased. Studies can now examine how self-reflection during times such as these, can impact and improve teaching techniques and student learning. And how selfreflection can reduce stress levels of faculty members and students. Also, whether and how the different types of technological pedagogies and group-based activities mentioned earlier can be incorporated into online classes.

\section{References}

[1] Boud, D. (2010), 'Relocating Reflection in the Context of Practice', in H. Bradbury, N. Frost, S.Kilminster, S., and M. Zukas (Eds.), Beyond Reflective Practice: New Approaches to Professional Lifelong Learning (pp. 25-36), Abingdon, Routledge.

[2] Dewey, J. (1910), How We Think, Boston, D. C. Heath and Co. Publishers.

[3] Williams, J. and Power, K. (2009), 'Using Core Reflection in Teacher Education', Refereed paper presented at Teacher Education Crossing Borders: Cultures, Contexts, Communities and Curriculum the Annual Conference of the Australian Teacher Education Association (ATEA), Albury, 28 June - 1 July.

[4] Marentic Pozarnik, B. (2000), 'Professionalizacija Izobraevanja uciteljev-Nujna Prepostavka Uspesne Prenove' (Professionalization of Teacher Education-Necessary Precondition of Successful School Reform), Vzgoja in izobrazevanje, 31 (4), 4-11.

[5] Korthagen, F. A. J. and Vasalos, A. (2005), 'Levels in Reflection: Core Reflection as a Means to Professional Growth', Teachers and Teaching: Theory and Practice, 11 (1), 47-71 https://doi.org/10.1080/1354060042000337093.

[6] Liu, K. (2015), 'Critical Reflection as a Framework for Transformative Learning in Teacher Education', Educational Review, 67 (2), 135-157. https://doi.org/10.1080/00131911.2 013.839546 .
[7] Schön, D. (1983), The Reflective Practitioner: How Professionals Think in Action, New York, NY: Basic Books.

[8] Brandenburg, R. (2008), Powerful Pedagogy, Dordrecht, The Netherlands, Springer.

[9] Saric, M. and Steh, B. (2017) 'Critical Reflection in the Professional Development of Teachers: Challenges and Possibilities', CEPS Journal, 7 (3), 67-85. https://eric.ed.gov/ ?id=EJ1156912 (Access Date: 12 April 2020).

[10] Freire, P. (1998), Pedagogy of Freedom: Ethics, Democracy, and Civic Courage, Lanham, MD, Rowman and Little.

[11] Smyth, J. (1992), 'Teachers' Work and the Politics of Reflection', American Educational Research Journal, 29, 267300, doi.org/10.3102/00028312029002268.

[12] Benade L. (2016), 'Teaching and Critically Reflective Practice' in Freire in M. Peters (eds) Encyclopedia of Educational Philosophy and Theory, Singapore, Springer.

[13] Brookfield. S. D. (2017), Becoming a Critically Reflective Teacher ( $2^{\text {nd }}$ edition), San Francisco, CA: Wiley.

[14] Ghaye, A. and Ghaye, K. (1998), Teaching and Learning through Critical Reflective Practice, London, David Fulton.

[15] Lave, J. and Wenger, E (1991), Situated Learning: Legitimate Peripheral Participation, New York, Cambridge University Press.

[16] Greiner, R. S. (2015), 'Autoethnography as a Legitimate Approach to HRD Research: A Methodological Conversation at 30,000 feet', Human Resource Development Review, 14 (3), 332-50.

[17] Maclure, M. (1993), 'Arguing for Yourself: Identity as an Organizing Principle in Teachers' jobs and lives', British Educational Research Journal, 19 (4), 311-322, doi.org/10.1080/0141192930190401.

[18] Neumayer Depiper, J. (2013), 'Teacher Identity Work in Mathematics, Teacher Education for the Learning Mathematics', 33 (1), 9-15. https://www.jstor.org/stable/4389 4833 (Access Date: 12 April 2020).

[19] Akkerman, S. F., and Meijer, P.C. (2011), 'A Dialogical Approach to Conceptualizing Teacher Identity', Teaching and Teacher Education, 27, 308-319. https://eric.ed.gov/?id=EJ 9 11677 (Access Date: 12 April 2020).

[20] Henry, A. (2016), 'Conceptualizing Teacher Identity as a Complex Dynamic System: The Inner Dynamics of Transformations during a Practicum', Journal of Teacher Education, 67(4), 291-305, doi.org/10.1177/0022487116655 382. 
[21] Bradbury, N. A. (2016), 'Attention Span during Lectures: 8 seconds, 10 minutes or More', Advanced Physiological Education, 40 (4), 509-513. 10.1152/advan.00109.2016.

[22] Cilliers, E. J. (2017), 'The Challenge of Teaching Generation Z People', International Journal of Social Sciences, 3(1). https://grdspublishing.org/index.php/people/ar ticle/view/322 (Access Date: 12 April 2020).

[23] Ladson-Billings, G. (1995), 'Toward a Theory of Culturally Relevant Pedagogy', American Educational Research Journal, 32 (3), 465-491, DOI: 10.2307/1163320.

[24] Miller, A., and Mills, B. (2019), 'If They don't Care, I don't Care': Millennial and generation Z Students and the Impact of Faculty Caring', Journal of the Scholarship of Teaching and Learning, 19(4), 78-89, doi: 10.14434/josotl.v1 9i4.24167.

[25] Wenger, E (1998), Communities of Practice: Learning, Meaning, and Identity, Cambridge, Cambridge University Press. 